九州大学学術情報リポジトリ

Kyushu University Institutional Repository

\title{
Study on the Japanese Calocarcelia Townsend and Eucarcelia Baranov (Diptera : Tachinidae)
}

Shima, Hiroshi

Entomological Laboratory, Department of Agriculture, Kyushu University

https://doi.org/10.5109/22778

出版情報: 九州大学大学院農学研究院紀要. 14 (4)，pp.507-533，1968-11. Kyushu University バージョン：

権利関係 : 
Journal of Faculty of Agriculture, Kyushu University, Vol. 14, No. 4

November 30, 1968

\title{
Study on the Japanese Calocarcelia Townsend and Eucarcelia Baranov (Diptera : Tachinidae) ${ }^{1}$
}

\author{
Hiroshi SHIMA $^{2}$
}

Hitherto have been known 8 genera of the tribe Carceliini from Japan. In this paper I treated 5 species of the genus Calocarcelia Townsend, of which 2 are new to science, and 7 species of the genus Eucarcelia Baranov, of which 2 are also new to science.

The tribe Carceliini is very characteristic in its very large eye (that is, gena narrower than parafrontal at the level of 1st antenna1 segment) and flattened occiput. The genera Calocarcelia and Eucarcelia are closely related to each other and are characteristic in their densely haired eye, facial ridge without any strong bristle, $1+1$ sternopleural bristles, presence of ocellar bristle, 2 marginal bristles of 2 nd abdominal tergum, etc. These genera are differentiated from each other by the position of basal humeral bristles, presence or absence of ventral seta of mid-tibia, hind coxa with or without setae on posterodorsal margin, and so on.

Materials treated in this study were mainly from my private collection and some were from the collections of the Entomological Laboratory of Kyushu University, Entomological Institute of Hokkaido University and Entomological Laboratory of Ehime University. All the holotypes, except for Eucarcelia japonica sp. nov., are deposited in the collection of the Entomological Laboratory of Kyushu University, and E. japonica sp. nov. is in the collection of the Entomological Institute of Hokkaido University.

Host records are mainly referred to "The Tentative Catalogue of Insect Natural Enemies of Injurious Insects from Japan (Yasumatsu and Watanabe, 1964)." Host insects observed in the foreign countries are excluded in this paper. Newly recorded host from Japan is marked with asterisk.

Terminology was mainly referred to Mesnil in 1944, but that of male genitalia was from Tuxen's book "Taxonomist's glossary of genitalia in. insects."

1. Contribution Ser. 2, No. 283. Entomological Laboratory, Faculty of Agriculture, Kyushu University, Fukuoka.

2. Entomological Laboratory, Faculty of Agriculture, Kyushu University, Fukuoka. 
Before going further I wish to express my cordial thanks to Prof. K. Yasumatsu and Prof. Y. Hirashima of the Entomological Laboratory, Kyushu University, for their kind and constant guidance. I am also much indebted to Dr. S. Takano of Sapporo City, for his kind suggestions during the course of this study, Dr. M. Shibuya of Kagoshima City for his generosity in lending me many invaluable literature, Prof. E. Ninomiya of Senshu University for his encouragement in many respects and Prof. C. Watanabe of Hokkaido University and Prof. T. Ishihara of Ehime University for giving me the oppotunities of examining the collections of their respective Universities. Particular thanks are also due to the following lady and gentlemen for their useful advice or for the gift of many materials : Dr. K. Baba, Mr. I. Hiura, Mr. Y. Ikezaki, Mr. Y. Miyatake, Miss M. Honda, Mr. K. Kanmiya, Mr. T. Kocha, Mr. K. Kusigemati, Prof. A. Nagatomi, Mr. A. Nakanishi, Mr. T. Okuno, Mr. T. Saigusa, Mr. M. Shiga, Mr. A. Tanaka, Dr. H. Tanaka, Prof. T. Torii, Dr. K. Yano and Mr. J. Yukawa.

Key to the genera of the tribe Carceliini from Japan

1. Eye bare, or at most very sparsely haired $\ldots \ldots \ldots \ldots \ldots \ldots \ldots \ldots \ldots \ldots{ }^{*} \ldots 2$ Eye densely with long hairs

2. 4 sternopleural bristles; 2 nd abdominal tergum with 2 distinct median marginal bristles................................................................... 3

2-3 sternopleural bristles; 2nd abdominal tergum with at most very fine hair-like setae; $3+4$ dorsocentral bristles . . . ....*. ........................................ Argyrophylax Brauer \& Bergenstamm, 1889

3. $2+4$ dorsocentral bristles; basal portion of vein $\mathrm{R}_{4+5}$ with only one fine seta; ocellar bristle fine, shorter than foremost frontal bristle; apical scutellar bristles in an upright position, i. e., perpendicular to the longitudinal axis of body and crossed each other ...**....*.

..............*.... Thelyconychia Brauer \& Bergenstamm, 1889

$3+4$ dorsocentral bristles; basal portion of vein $\mathrm{R}_{4+5}$ with 2 or more setae ; ocellar bristle strong ; apical scutellar bristles horizontal and crossed Thecocarcelia Townsend, 1932

4. Fore claw of male shorter than 5th tarsomere, at most subequal in length; frontal length longer than facial one in profile ; hind coxa setulose posterodorsally ; mid-tibia with 1 ventral seta . ...*............. 5

Fore claw of male longer than 5th tarsomere, if shorter, facial length longer than frontal one..........................................................6

5. Ocellar bristle absent; 5th abdominal tergum with dense, rather long and erect hairs ; hairs on abdomen dense and fine; fore claw of male shorter than 5 th tarsomere or nearly as long as that ....................... 
Ocellar bristle present ; 5 th abdominal tergum without such hairs ; hairs on abdomen rather sparse ..............Carceliopsis Townsend, 1927

6. Ocellar bristle absent; hind coxa setulose posterodorsally ; mid-tibia without any ventral seta; hairs on abdomen fine and not erect; scutellum entirely black ; abdominal terga without discal bristle; venter of 4th and 5th abdominal terga of male with a pair of dense hair-patches; parafrontal rounded in profile Carceliella Baranov, 1934 Ocellar bristle present; venter of male of 4 th and 5th abdominal terga without such hair-patches

7. Middle basal humeral bristle strongly set forward ; hind coxa setulose posterodorsally ; fore tibia with 2 posterior setae

Calocarcelia Townsend, 1926

Basal humeral bristles in a line, if middle one set forward, hind coxa bare posterodorsally .................................................................. 8

8. Mid-tibia without any ventral seta ; hind coxa without any seta posterodorsally ; abdomen without any discal bristle ; fore claw and pulvillus in male longer than 5th tarsomere; basiphallus of aedeagus in male genitalia with a distinct dorsal process

Eucarcelia Baranov, 1934

Mid-tibia with a ventral seta; hind coxa usually with several fine setae posterodorsally (in the subgenus Carcelina Mesnil hind coxa bare posterodorsally) ; fore tibia usually with 2 posterior setae

Carcelia Robineau-Desvoidy, 1830

Genus Calocarcelia Townsend, 1926

(Type species : Musca cingulata Fabricius, 1805. Original designation)

Calocarcelia Townsend, 1926, Gen. Musc. Hum. trop. Amer. : 266.

Myxocarcelia Baranov, 1934, Trans. R. ent. Soc. London LXXXII: 398.

Calocarcelia: Townsend, 1941, Manual of Myiology XI, São Paulo : 142.

Myxocarcelia: Mesnil, 1944, Larvaevorinae (Tachininae) in Lindner "Die Flieg. der paläarkt. Reg. 64g" : 29 (as subgenus, in key).

Calocarcelia: Mesnil, 1953, Bull. et Ann. Soc.Entom. de Belgique 89 (IIIIV) : 88 .

Head almost black, with silvery white or yellow pollinosity ; antenna with 3rd segment almost black; palpus yellow. Vertex less than $2 / 3$ of single eye width in male; parafacial narrowed below, narrower than the width of 3rd antenna1 segment at middle, or at most nearly as wide as that; gena very narrow ; ocellar bristle strong ; 2 reclinate inner orbital bristles present ; outer orbital bristle absent in male; antenna with 3rd 
segment elongated, more than 4.5 times of 2nd segment. Eye densely haired.

Thorax almost black, with greyish or yellowish pollinosity ; scutellum reddish yellow at least posterior half. Three humeral bristles, of which middle one set forward; $3+4$ dorsocentrals; 2 sternopleurals ; 4 pairs of marginal scutellar bristles, preapical scutellar bristle usually present.

Wing hyaline, sometimes with brownish tinge anteriorly and along veins. Costa1 spine indistinct or fine ; basal portion of vein $R_{4+5}$ with $2-3$ fine setae; 2 nd costal section bare ventrally.

Legs black; tibia sometimes reddish yellow at middle. Hind coxa with several fine setae on posterodorsal margin. Fore tibia with 2 posterior setae; mid-tibia with 1 anterodorsal and 2-3 posterodorsal setae, ventral seta sometimes absent. Fore claw and pulvillus sometimes longer than 5th tarsomere.

Abdomen black, sometimes broadly reddish at sides, with greyish or yellowish pollinosity. Median marginal bristles present on 2 nd tergum ; 5 th tergum with a row of discal bristles.

Male genitalia: Basiphallus of aedeagus usually without any distinct dorsal process (epiphallus) ; distiphallus of aedeagus sometimes with very fine spines on non-sclerotized area.

Key to the species of the genus Calocarcelia from Japan

1. Tibia brown or reddish brown; wing tinged with brown anteriorly; basicosta brown-black ; hairs on abdomen rather erect, strong and bristle-

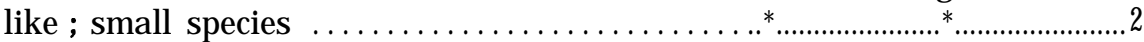

Tibia yellow, at most darkened basally and apically; wing slightly with yellowish tinge anteriorly and along veins ; hairs on abdomen not much erect strong bristle-like, except discal bristles ; medium in size . . . . . . 3

2. Preapical scutellar bristle absent ; abdomen entirely black ; thorax with 5 black vittae, of which middle one is indistinct on prescutum ; antenna with $3 \mathrm{rd}$ segment nearly $5.5 \mathrm{x}$ as long as $2 \mathrm{nd}$; intermediate abdominal terga without discal bristles ; cercus of male genitalia shorter than surstylus and pointed at apex ...................... hirsuta (Baranov, 1931)

Preapical scutellar bristle present; abdomen reddish at sides of $3 \mathrm{rd}$ and 4 th terga; thorax with distinct 5 black vittae on prescutum and scutum; 3rd segment of antenna nearly $5 \mathrm{x}$ as long as 2nd; irregular discal bristles present on 3rd to 5th abdominal terga ; surstylus shorter than cercus I......................................................... shibuyai sp. nov.

3. Antenna almost entirely black; femur and tarsus black ; intermediate abdominal terga with rather irregular discal bristles ................... 4 Second segment of antenna entirely, at least interiorly, reddish; femur anteriorly and tarsus entirely reddish yellow ; basicosta reddish yellow ; 
abdomen without discal bristles on intermediate terga; mid-tibia with 1 ventral seta...................*............................ excisoides Mesnil, 1957

4. Mid-tibia with 1 ventral seta; fore claw and pulvillus in male shorter than 5th tarsomere; basicosta black ; surstylus of male genitalia nearly as wide as cercus in profile takanoi Mesnil, 1957

Mid-tibia without any ventral seta; fore claw and pulvillus in male longer that 5th tarsomere; basicosta reddish yellow; surstylus in profile very wide, wider than cercus ; basiphallus with a short but distinct dorsal process ..... yakushimana sp. nov.

\section{Calocarcelia hirsuta (Baranov, 1931) comb. nov.}

(Fig. 1)

Carcelia hirsuta Baranov, 1931, Inst. f. Hyg. Arb. Parsit. Abt. 3 : 38.

Myxocarcelia hirsuta : Baranov, 1934, Trans. R. ent. Soc. London LXXXII: 398.

Male: Head black; gena below eye and anterior part of parafacial very narrowly reddish ; epistoma narrowly pale yellow ; parafrontal, parafacial and face with silvery white pollinosity ; pollinosity on parafrontal somewhat yellowish ; frontal stripe black ; antenna entirely black ; arista brown-black ; palpus yellow. Frontal length nearly as long as facial one in profile; vertex nearly $1 / 2$ of single eye width ; frontal stripe nearly parallel sided, nearly $1 / 2 \times$ as wide as parafrontal at middle; parafacial very narrow, nearly $2 / 5 \times$ as wide as the width of $3 \mathrm{rd}$ antenna1 segment at middle ; facial ridge nearly straight in profile ; face well concave, nearly $3 / 8 \mathrm{x}$ as wide as long between vibrissae; epistoma not projected but nearly on facial plane ; gena very narrow, less than $1 / 20$ of eye height. Inner vertical bristle slightly over 1/3 of eye height; ocellar bristle strong; 2 inner orbital bristles present, anterior one slightly stronger than posterior one, and nearly as long as ocellar bristle; 2 rather long postocellar setae present; 1 fine postvertical seta on each side ; 8-9 frontal bristles, of which 3 descend to parafacial and the undermost is at the level of base of arista; facial ridge with a few setae on its lower $1 / 5$; vibrissa nearly as long as 3rd antenna1 segment. Antenna with 3rd segment elongated, nearly $5.5 \mathrm{x}$ as long as 2nd. Arista with 2nd segment as long as wide ; 3rd segment thickened on basal 1/3. Palpus cylindrical, very slightly widened and flattened apically, with black hairs.

Thorax black, postalar callus reddish, with thin greyish white pollinosity; 5 rather broad black vittae present, of which middle one is indistinct on prescutum; scutellum reddish yellow, basally very narrowly darkened, with very thin white pollinosity. Hairs on dorsum long, dense and erect, 
on pleura longer; barette bare; 3 humerals, of which middle one strongly set forward ; 1 very fine prehumeral ; 2 posthumerals, anterior one slightly stronger $; 3 \div 3$ acrostichals $; 3+4$ dorsocentrals $; 1+3$ intraalars ; 3 supraalars , pre-alar weaker than 3 rd supraalar ; 1 presutural ; 2 notopleurals $; 1+1$ sternopleurals, anterior one weaker ; 6 hypopleurals, the uppermost one weak. Hairs on scutellum strong and erect ; subapical scutellar bristle nearly 2 $\mathbf{x}$ as long as scutellum and apical scutellar bristle ; lateral scutellar bristle nearly $3 / 5 \mathrm{x}$ as long as subapical scutellar bristle ; basal scutellar bristle slightly shorter than subapical one; preapical scutellar bristle absent. Distance between two subapical scutellar bristles very slightly longer than that between subapical and basal ones of same side.

Wing hyaline, with pale brownish tinge anteriorly ; basicosta black ; veins brown; calypter white. Costa1 spine fine ; basal portion of vein $R_{4+5}$ with 2 fine setae. Proportion of costal section 2 nd, 3rd and 4 th as $5: 9: 5$. Length of vein $\mathrm{M}_{1}$ from $t p$ to bending portion nearly $2 / 3 \mathrm{x}$ as long as that from bending portion to anterior end of vein $M_{1}$.

Legs black, tibia reddish, basally and apically darkened; pulvillus yellow. Hind coxa with a few bristle-like hairs on posterodorsal margin. Fore tibia with two posterior setae; mid-tibia with 1 anterodorsal and 2 posterodorsal setae, ventral seta absent; hind tibia with a row of anterodorsal setae, which are not much closely set, a strong anterodorsal seta present near the middle, 1 posterodorsal and several ventral setae. Fore claw and pulvillus very long.

Abdomen entirely shining black ; anterior $4 / 5$ of $3 \mathrm{rd}, 2 / 3$ of 4 th and $3 / 4$ of 5 th terga with thin silvery white pollinosity. Hairs on dorsum erect, rather sparse and bristle-like, especially on mid-dorsal region of intermediate terga and on 5 th tergum, on venter finer and not much erect ; 2nd and 3rd terga with 2 marginal bristles; 4th tergum with a row of marginal bristles ; 5 th tergum with rows of discal and marginal bristles.

Male genitalia : Cercus and surstylus in profile slender, bent ventrally ; cercus shorter than surstylus and pointed at apex; ventral part of distiphallus narrow in profile; basiphallus without epiphallus ; ejacuratory apodeme contained in large membrane.

Body length: $7 \mathrm{~mm}$.

Female : Unknown.

Host : Unknown.

Distribution : Formosa and Japan (Kyushu).

Specimen examined : 1ð, Mt. Inunakiyama, Fukuoka Pref., 20. ix. 1966, H. Shima leg.

Remarks : This species was originally described by only one male obtained from Formosa. The specimen collected on Mt. Tnunakiyama, Kyushu, 
well corresponded to the original description of Baranov.

This species is very characteristic in its very narrow paraf acial and gena, strong bristle-like hairs on abdomen, entirely blackish color and the absence of preapical scutellar bristle.

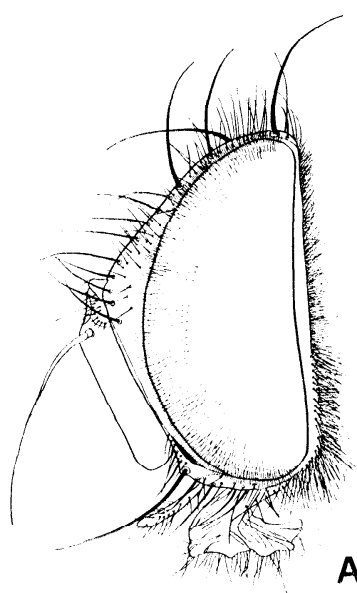

A

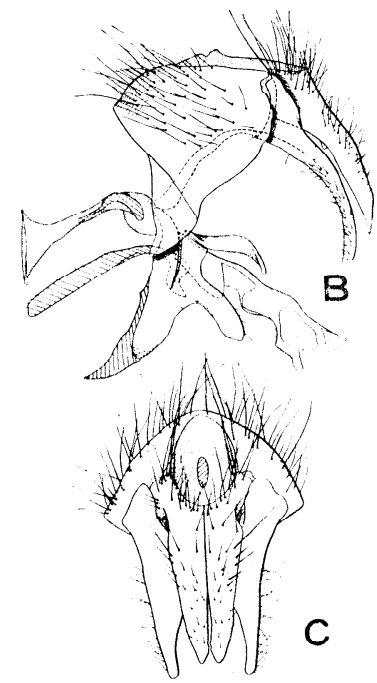

Fig. 1. Calocarcelia hirsuta Baranov.

A : Head in profile, B : Male hypopygium, lateral view, C: same, dorsal view.

\section{Calocarcelia shibuyai sp. nov.}

(Fig. 2)

Male: Head black; gena below eye reddish; epistoma pale yellow; parafrontal and face with silvery white pollinosity; pollinosity on parafrontal becoming gradually blackish to vertex ; frontal stripe brown-black ; occiput greyish white pollinose; antenna and arista black ; palpus dull yellowish. Frontal length longer than facial one in profile; vertex narrower than $1 / 2$ of single eye width ; frontal stripe very narrow, nearly $1 / 2 \mathrm{x}$ as 'wide as parafrontal at middle; parafacial narrowed below, nearly $1 / 3 \mathrm{x}$ as wide as width of 3rd antenna1 segment at middle; gena very narrow, nearly $1 / 18$ of eye height; face well concave, nearly $4 / 9 \mathrm{x}$ as wide as long between vibrissae. Parafrontal densely with very fine hairs, which do not descend below the undermost frontal bristle ; inner vertical bristle nearly $1 / 3$ of eye height ; 2 reclinate inner orbital bristles, anterior one stronger ; ocellar bristle nearly as long as anterior inner orbital bristle ; 8 frontal bristles, of which 3 descend to parafacial and the undermost is at the level of an- 
terior end of 2 nd antenna1 segment ; 1 postvertical seta on each side ; 2 fine postocellar setae; facial ridge with 8-10 very fine setae on its lower $1 / 6$. Antenna with 3rd segment long and stout ; 3rd segment nearly $5 \mathrm{x}$ as long as 2nd. Arista longer than the entire length of antenna ; 2nd segment wider than long; 3rd segment thickend on basal 1/3. Palpus club-like in form, with several hairs apically.

Thorax shining black, postalar callus and anterior part of hypopleura reddish ; scutellum reddish yellow, darkened anteriorly ; dorsum and pleura thin greyish pollinose ; pollinosity on scutellum very thin; prescutum and scutum with 5 narrow black vittae, of which midde one is rather inconspicuous on prescutum. Hairs on dorsum fine and dense, on pleura more fine and longer; barette with 1 very fine seta on anterior part; 3 humerals, of which middle one rather slightly set forward ; 2 subequally long posthumerals $; 3+3$ acrostichals $; 3+4$ dorsocentrals; $1+3$ intraalars; 3 supraalars, pre-alar weaker than 3rd supraalar; 1 very weak intrapostalar; 1 presutural; 2 notopleurals ; $1+1$ sternopleurals, anterior one weaker; 5-6 hypopleurals. Hairs on scutellum erect rather strong and sparse; preapical scutellar bristle fine but distinct, and shorter than apical scutellar bristle; subapical and basal scutellar bristles subequal in length, and nearly $3 / 5 \mathbf{x}$ as long as scutellum ; lateral and apical scutellar bristles nearly $3 / 5 \mathbf{x}$ as long as subapical one. Distance between two subapical scutellar bristles nearly $1.5 \mathrm{x}$ as long as that between basal and subapical scutellar bristles of same side.

Wing hyaline, with very pale brownish tinge anteriorly ; basicosta black ; veins brown ; calypter white, somewhat yellowish. Costa1 spine indistinct; basal portion of vein $\mathrm{R}_{4+5}$ with two fine setae. Second costal section subequal in length to 4 th, and nearly $4 / 7 \mathbf{x}$ as long as $3 \mathrm{rd}$; length of vein $\mathrm{M}_{1}$ from $t p$ to bending portion nearly $2 / 3 \mathrm{x}$ as long as that from bending portion to anterior end of vein $M_{1}$.

Legs brown-black ; tibia reddish yellow ; pulvillus yellow. Hind coxa with several setae on posterodorsal margin. Fore tibia with two posterior setae ; mid-tibia with 1 anterodorsal and 2 posterodorsal setae, without ventral seta; hind tibia with a row of anterodorsal setae, which are not much closely set, middle one of anterodorsal seta stronger than the others, l-2 posterodorsal and 2-3 ventral setae. Fore claw and pulvillus longer than 5 th tarsomere.

Abdomen long ovate ; shining black, sides of 2nd, 3rd and 4th terga reddish ; venter of 2 nd, 3rd and 4th terga almost entirely reddish brown; thin silvery white pollinosity on entire 3rd tergum, on anterior $3 / 4$ of 4 th and anterior $2 / 3$ of 5 th terga; black median longitudinal line distinct. Hairs on dorsum strong, erect and bristle-like, especially on mid-dorsal region of 3rd and 4th terga and on 5th tergum ; 2nd tergum with 2 marginal bristles ; 3rd tergum with 2 marginal and 2 weak irregular discal bristles; 4th 
tergum with a row of marginal and 2 weak irregular discal bristles; 5 th tergum with a row of marginal and an irregular row of discal bristles; discal bristles on 3rd to 5th terga mixed with erect bristle-like hairs. Hairs on venter fine and not erect.

Male genitalila: Cercus strongly bent ventrally in profile; each cercus widely separated at apical $2 / 5$ and associated at apex in dorsal view ; surstylus shorter than cercus and slightly bent ventrally in profile, with rather sparse hairs ; basiphallus without any dorsal process ; ventral part of distiphallus very broad ; spines on non-sclerotized area of distiphallus widely distributed ; ejaculatory apodeme rather long.

Body length : $6 \mathrm{~mm}$.

Female : Unknown.

Holotype ðð, Terayama Park, Kagoshima City, Kyushu, 29. v. 1965, H. Shima leg.

Host : Unknown.

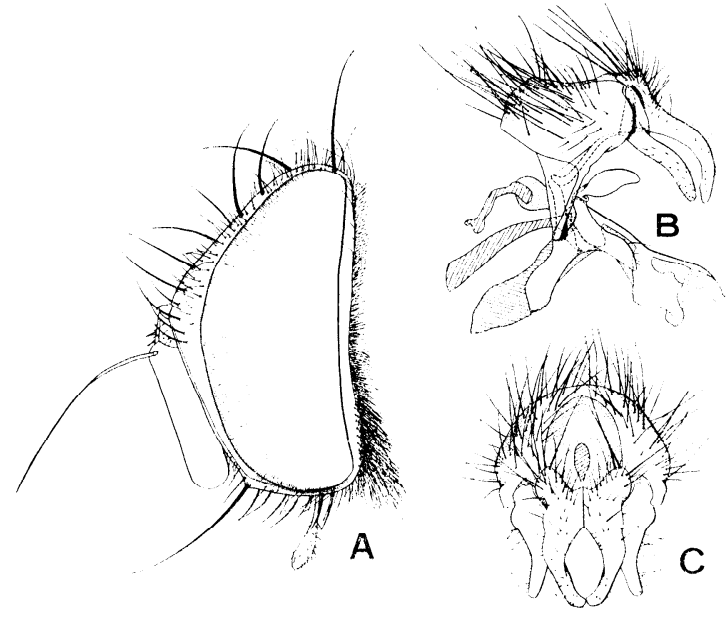

Fig. 2. Calocarcelia shibuyai sp. nov.

A: Head in profile, B: Male hypopygium, lateral view, C : same, dorsal view.

Rema $: \subset$ : This species is closely related to Calocarcelia hirsuta (Baranov), but easily diı, mentiated by the presence of preapical scutellar bristles, broadly reddish siuc of 3rd and 4th abdominal terga and the structure of male genitalia. 


\section{Calocarcelia yakushimana sp. nov.}

(Fig. 3A, Fig. 4 A, B)

Male : Head black ; gena below eye and anterior and posterior parts of parafacial reddish ; epistoma pale yellow ; frontal stripe black ; face, parafacial, parafrontal and occiput silvery white pollinose ; pollinosity on parafrontal becoming gradually blackish to vertex, and that on occiput greyish ; antenna black, anterior end of 2nd segment reddish; arista brown-black ; palpus yellow. Facial length slightly shorter than frontal one in profile ; vertex nearly $1 / 2 \mathrm{x}$ as wide as single eye width ; frontal stripe nearly $1 / 2$ $\mathrm{x}$ as wide as parafrontal at middle ; parafacial nearly $2 / 3 \mathbf{x}$ as wide as width of 3rd antenna1 segment at middle; face well concave; epistoma hardly projected forward ; gena very narow, nearly $1 / 16$ of eye height. Parafrontal with fine and dense hairs, which do not descend below the undermost frontal bristle ; inner vertical bristle distinct ; 2 long postocellar setae ; 1 fine postvertical seta on each side; 2 reclinate inner orbital bristles, and one weak additional bristle present behind posterior one, anterior one stronger than the others ; ocellar bristle strong, nearly as long as posterior inner orbital bristle ; 9 frontal bristles, of which 3 descend to parafacial and the undermost is at the level of anterior end of 2nd antenna1 segment; facial ridge with 4-5 fine setae on its lower 1/5. Antenna long and stout; 3 rd segment nealy $4.5 \mathrm{x}$ as long as $2 \mathrm{nd}$. Arista with 2 nd segment very short ; 3rd segment thickened on basal 1/4. Palpus slender, flattened apical$1 \mathrm{y}$.

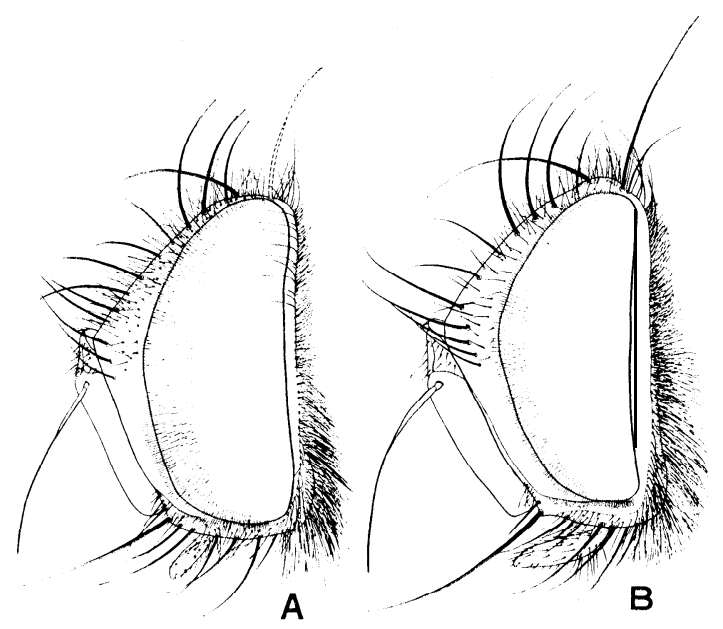

Fig. 3. Head in profile.

A : Calocarcelia yakushimana sp. nov., B : Calocarcelia takanoi Mesnil. 
Thorax black, posterior edge of humeral callus and postalar callus reddish ; scutellum yellow, slightly darkened basally ; dorsum and pleura greyish white pollinose ; 5 distinct black vittae present on prescutum and scuturn; pollinosity on scutellum very thin. Hairs fine and dense on dorsum,

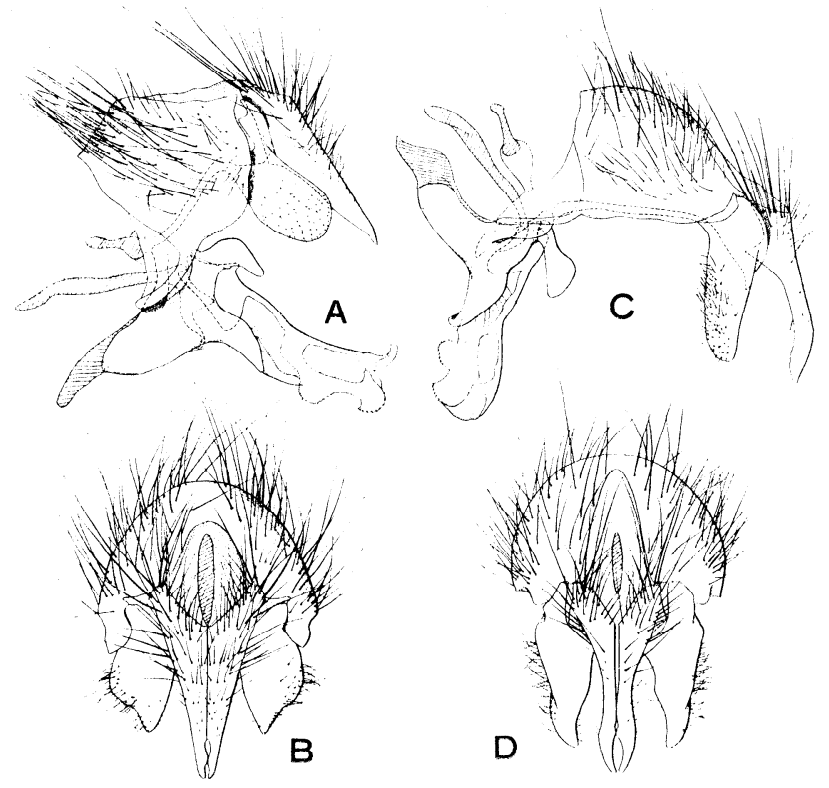

Fig. 4. Male hypopygium.

A, C lateral view; B, D dorsal view. A, B : Calocarcelia yakushimana sp. nov. ; C, D : Calocarcelia takanoi Mesnil.

on pleura longer, on scutellum more erect and longer; baratte with f-2 very fine hairs on anterior part ; 3 humerals, middle one set forward ; 2 posthumerals, anterior one stronger ; 1 very fine hair-like prehumeral: $3+$ 2 acrostichals (normally $3+3$ ?) $; 3+4$ dorsocentrals $; 1+3$ intraalars ; 3 supraalars, pre-alar weaker than 3rd supraalar ; 1 fine intrapostalar ; 2 notopleurals ; $1+1$ sternopleurals, anterior one fine ; 6-7 hypopleurals, uppermost one hair-like. Subapical scutellar bristle very long, nearly $1.8 \mathrm{x}$ as long as scutellum, and slightly longer than basal scutellar bristle; lateral scutellar bristle very fine, shorter than preapical one ; apical scutellar bristle nearly $2 / 3 \mathbf{x}$ as long as subapical scutellar one, and $1.2 \mathbf{x}$ as long as preapical one. Distance between two subapical scutellar bristles subequal in length to that between subapical and basal ones of same side.

Wing hyaline, very slightly tinged with yellow basally and anteriorly ; basicosta yellow ; calypter white, Costa1 spine indistinct ; basal portion of 
vein $R_{4+5}$ with 2-3 fine setae. Second costal section slightly longer than 4 th, and nearly $3 / 4 \times$ as long as $3 r d$; length of vein $M_{1}$ from $t p$ to bending portion nearly $3 / 5 \times$ as long as that from bending portion to anterior end of vein $\mathbf{M}_{1}$.

Legs brown-black ; tibia distinctly yellow ; pulvillus dull yellowish. Hind coxa with several setae on posterodorsal margin. Fore tibia with 2 posterior setae ; mid-tibia with 1 anterodorsal and 2 posterodorsal setae, ventral seta absent; hind tibia with a regular row of anterodorsal setae, which are not closely set, middle one of anterodorsal seta stronger than the others, 2-3 posterodorsal and several ventral setae. Fore claw and pulvillus longer than 5th tarsomere.

Abdomen black, somewhat shining ; sides of 2nd and 3rd terga and anterior narrow sides of 4th tergum reddish ; venter almost entirely brownish ; greyish white, somewhat silvery, pollinosity on 3rd to 5th terga ; hind margin of each tergum very narrowly shining black ; venter with silvery white pollinosity. Hairs dense, fine, long and erect; 2nd tergum with 2 marginal bristles; 3rd tergum with 4 marginal bristles; 4th tergum with a row of marginal and 2 weak irregular discal bristles, mixed with erect long hairs ; 5 th tergum with a row of marginal and an irregular row of discal bristles, mixed with erect bristle-like hairs; hairs on venter fine and not erect.

Male genitalia : Cercus in profile gradually becoming slender to apex and pointed at tip; surstylus very wide in profile with fine and rather dense hairs; basiphallus with a very short dorsal process; spines on non-sclerotized area of distiphallus narrowly distributed.

Body length: $11 \mathrm{~mm}$.

Female : Unknown.

Holotype ${ }^{\top}$, Kosugidani, Is. Yakushima, Kyushu, 28. vi. 1965, H. Shima leg.

Host : Unknown.

Remarks : This species is characterisitic in its very weak lateral scutellar bristle and the structure of male genitalia. In this specimen the postsutural acrostichal bristles are only two, but at the moment I can not determine whether this condition is normal or not.

\section{Calocarcelia takanoi Mesnil, 1957}

(Fig. 3B, Fig. 4C, D)

Calocarcelia takanoi Mesnil, 1957, Mém. Soc. Roy. Ent. Belg. XXVIII :1. Calocarcelia takanoi : Mesnil \& Pschorn-Walcher, 1967, Mushi 41(12) : 151.

This and the following species are differentiated from the above thre 
species by the presence of ventral seta of mid-tibia.

Male genitalia: Cercus and surstylus resembling that of Carcelia hemimacquartioides; cercus in profile basally thickened and becoming slender at basal $3 / 5$, weakly bent ventrally ; surstylus rather wide ; basiphallus without dorsal process; pregonite with rather dense fine hairs.

Distribution : Japan (Hokkaido and Honshu).

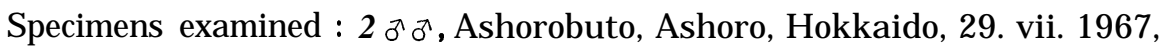
M. Honda leg.

Host: Unknown.

\section{Calocarcelia excisoides Mesnil, 1957}

Calocarcelia excisoides Mesnil, 1957, Mém. Soc. Roy. Ent. Belg. XXVIII : 3. Calocarcelia excisoides : Mesnil \& Pschorn-Walcher, 1967, Mushi 41 (12) : 151.

This species is closely related to the preceding one, but is distinguished as follows: 2nd antenna1 segment almost entirely reddish yellow; parafacial nearly as wide as the width of 3rd antenna1 segment at middle; basicosta yellow ; intermediate abdominal terga without any discal bristle ; femur yellowish at apical $1 / 4$; tarsus yellowish. This species is, however, more closely related to Carcelia (Carcelina) pallidipes Uéda. I could not obtain this species.

Distribution : Japan (Hokkaido).

Host : Unknown.

Genus Eucarcelia Baranov, 1934

(Type species : Tachina excisa Fallen, 1820. Original designation)

Eufischeria Brauer \& Bergenstamm, 1891, Denkschr. Akad. Wien LVIII : 163 (partim).

Senometopia Macquart, 1883, Mém. Soc. Sci. Lille : 296 (partim).

Tricarcelia Baranov, 1934, Trans. R. ent. Soc. London LXXXII : 389.

Eucarcelia Baranov, 1934, Ibid. : 389.

Senometopia: Townsend, 1941, Manual of Myiology XI, São Paulo: 159.

Eucarcelia: Mesnil, 1944, Larvaevorinae (Tachininae) in Lindner "Die Flieg. der paläarkt. Reg. 64g" : 31 (as subgenus).

Eucarcelia : Herting, 1960, Monog. zur Angew. Ent. 16 : 87.

Eucarcelia : Mesnil, 1963, Bull. Inst. r. Sci. nat. de Belgique XXXIX(24) :4.

Head almost black, with silvery white, greyish or golden yellow pollinosi- 
ty ; antenna black, 2nd segment rarely reddish ; palpus yellow. Facial length nearly as long as or slightly longer than frontal one in profile ; face well concave ; epistoma slightly projected forward, but not beyond the base of vibrissae in profile; occiput flattened. Ocellar bristle strong; 2 reclinate inner orbital bristles present ; outer orbital one absent in male; facial ridge with at most several hairs on its lower $1 / 4$; occiput without any black setae on its upper half. Eye with dense fine hairs.

Thorax almost black, with greyish white or yellowish pollinosity ; scutellum yellowish posteriorly, rarely entirely black. Three or four humeral bristles, basal ones in a line ; $3+3$ or $3+4$ dorsocentrals; $3+3$ acrostichals; $1+1$ sternopleurals ; scutellum with 4 pairs of marginal scutellar bristles and 1 pair of preapical scutellar ones.

Legs black ; femur rarely reddish ; tibia sometimes yellowish. Hind coxa bare posterodorsally ; mid-tibia with 1 anterodorsal and 2 posterodorsal setae, ventral seta absent.

Wing hyaline; veins brown; calypter white or somewhat yellowish white. Costa1 spine fine or indistinct; 2nd costal section bare ven.trally.

Abdomen black, sometimes reddish at sides of 2 nd to 4 th terga, with greyish white or yellowish pollinosity. Second abdominal terga with 2 median marginal bristles ; discal bristle sometimes absent on intermediate terga.

Male genitalia : Basiphallus of aedeagus with a distinct epiphallus.

Key to the species of the genus Eucarcelia from Japan

1. $3+4$ dorsocentral bristles

$3+3$ dorsocentral bristles ; scutellum entirely black ; legs entirely black ; abdomen entirely black, with rather thin whitish pollinosity; hairs on abdomen more or less strong and sparse; fore tibia with 1 posterior seta; 3rd antenna1 segment $4 \times$ as long as 2 nd

japonica sp. nov.

2. Legs entirely reddish yellow; abdomen broadly reddish very thinly with golden yellowish pollinosity ; basicosta reddish yellow ; 2nd antenna1 segment entirely reddish ; 3rd antenna1 segment nearly $4.5 \mathrm{x}$ as long as 2nd ; fore tibia with I posterior seta orientalis sp. nov.

At least femur black or brownish black ; abdomen reddish at sides of 3rd to 4 th terga; basicosta black or reddish brown ...................... 3

3. Tibia entirely black or brownish black ................................... 4 Tibia yellow or reddish yellow, at most darkened apically and basal-

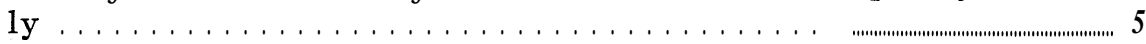

4. 5th abdominal tergum with short and not erect pilose; pollinosity on dorsum of thorax (including scutellum) and abdomen golden yellow ; 
fore tibia with 2 posterior setae ; anterior inner orbital bristles $2 \mathrm{x}$ as long as ocellar bristle; distance between two subapical scutellar bristles slightly shorter than that between basal and subapical scutellar ones of same side.............................................. nudicauda Mesnil, 1967

Hairs on 5th abdominal tergum rather erect and bristle-like ; pollinosity on dorsum of thorax and abdomen yellowish grey ; fore tibia with only one posterior seta; ocellar bristle nearly as long as inner orbital bristles ; distance between two subapical scutellar bristles nearly $5 / 3 \mathrm{x}$ as long as that between basal and subapical scutellar ones of same side; gena nearly $1 / 10$ of eye height

kockiana (Townsend, 1924)

5. Subapical scutellar bristle less than twice the length of scutellum; abdomen ovate, slighty longer than wide ; 4th abdominal tergum sometimes with rather weak irregular discal bristles, especially in female ; marginal bristles on 3rd abdominal tergum shorter than length of 4 th tergum ; pollinosity golden yellow or yellowish grey ; vertex nearly $2 / 3 \times$ as wide as single eye width; fore tibia with only one posterior seta... excisa (Fallen, 1820)

Subapical scutellar bristle $2 \mathrm{x}$ as long as, or more, scutellum ; abdomen rather elongated, nearly $2 \mathrm{x}$ as long as wide ; 3rd and 4th abdominal terga with 2 irregular discal bristles, in female stronger ; marginal bristles of 3rd tergum longer than the length of 4 th tergum; vertex slightly over $1 / 2$ of single eye width

6. Fore tibia with only one posterior seta; pollinosity entirely greyish ; parafacial nearly as wide as the width of 3rd antenna1 segment at middle. villeneuvei Mesnil, 1963

Fore tibia with 2 posterior setae; pollinosity golden yellow ; parafacial narrower than the width of 3 rd antenna1 segment at middle ..............

pollinosa Mesnil, 1941.

\section{Eucarcelia orientalis sp.nov.}

(Fig. 5A, B, Fig. 7A)

Male : Head black ; anterior part of parafacial, face and gena below eye reddish ; epistoma pale yellow ; frontal stripe brown-black ; parafacial, face and parafrontal silvery white pollinose; pollinosity on parafrontal being somewhat yellowish; antenna with 1st and 2nd segments entirels; and 3rd segment basally reddish yellow, other parts black; arista brownblack ; palpus yellow. Facial length nearly as long as frontal one in profile; vertex nearly $3 / 4 \mathrm{x}$ as wide as single eye width; frontal stripe nearly parallel sided, slightly narrower than parafrontal at middle; parafacial narrowed below, nearly $1 / 2 \mathrm{x}$ as wide as width of $3 \mathrm{rd}$ antenna1 segment at middle ; gena nearly $1 / 11$ of eye height ; face well concave ; 
epistoma slightly projected forward, but not beyond vibrissal angle. Parafrontal with fine and rather sparse hairs, which do not descend below the undermost frontal bristle ; inner vertical bristle nearly $2 / 5$ of eye height ; outer vertical bristle hair-like but distinct ; 2 inner orbital bristles, anterior one stronger than posterior one, and slightly shorter than inner vertical bristle ; ocellar bristle nearly as long as anterior inner orbital bristle; 2 postocellar setae ; 1 postvertical seta on each side; 6-7 frontal bristles, of which 2-3 are descending to parafacial and the undermost is at the level of base of arista; vibrissa slightly shorter than arista; facial ridge with 4-5 fine setae on its lower 1/6. Antenna long and wide, 3rd segment nearly 4.5 $\mathrm{x}$ as long as 2nd. Arista long, longer than the entire length of antenna; 2nd segment wider than long; 3rd segment thickened on nearly basal 1/3. Palpus widened and slightly flattened apically, rather sparsely with short black hairs.

Thorax black, humeral callus, postalar callus and anterior part of hypopleura reddish, with rather dense yellowish pollinosity ; pollinosity on pleura more whitish; dorsum with 5 black vittae, of which middle one is rather inconspicuous ; scutellum reddish yellow, anteriorly broadly darkened, with thin golden yellowish pollinosity. Hairs on dorsum fine, dense and suberect, on pleura longer; barette with 1 fine seta on anterior part; 4 humerals, of which foremost one is hair-like and 3 basals are in a line ; 1 weak prehumeral; 2 posthumerals ; $3+3$ acrostichals ; $3+4$ dorsocentrals ; $1+3$ intraalars; 3 supraalars, pre-alar weaker than 3rd supraalar; 1 weak intrapostalar ; 1 presutural ; 2 notopleurals ; $1+1$ sternopleurals ; 5 hypopleurals. Scutellum semicircular; hairs strong and short; basal and subapical scutellar bristles subequal in length, and slightly over $3 / 5$ of the length of scutellum ; apical and lateral scutellar bristles nearly $4 / 5 \mathrm{x}$ as long as subapical one. Distance between two subapical scutellar brisitles neary $1.5 \mathrm{x}$ as long as that between subapical and basal scutellar bristles of same side.

Wing hyaline, with slightly yellowish tinge anteriorly ; basicosta reddish yellow ; calypter pale yellowish white. Costa1 spine indistinct ; basal portion of vein $R_{4+5}$ with 2 fine hairs. Proportion of costal section $2 \mathrm{nd}$, 3rd and 4 th as $5: 9: 5$. Length of vein $\mathrm{M}_{1}$ from $t p$ to bending portion nearly $2 / 3 \mathrm{x}$ as long as that from bending portion to anterior end of vein $M_{1}$.

Legs entirely reddish yellow; pulvillus yellow. Hind coxa bare posterodorsally. Fore tibia with 1 posterior seta; mid-tibia with 1 anterodorsal and 2 posterodorsal setae, ventral seta absent ; hind tibia with a row of anterodorsal seta, of which middle one is stronger, 6-7 hair-like posterodorsal and 3-4 ventral setae. Fore claw and pulvillus longer than 5th tarsomere.

Abdomen long ovate ; reddish with thin golden pollinosity ; middle parts of 2 nd and 3rd terga, posterior triangular part of 4 th tergum and anterior $2 / 3$ of 5 th tergum black ; apex of 5 th tergum reddish brown. Hairs on dorsum dense, fine and not erect; 2 nd and 3rd terga with rather short 2 margi- 
nal bristles; 4th tergum with a row of marginal bristles; 5 th tergum with rows of distinct discal and marginal bristles, mixed with rather long erect hairs.

Male genitalia : Cercus in profile constricted at apical 2/7; surstylus broad, nearly parallel-sided, and. rounded at apex in profile, with sparse fine hairs ; epiphallus turned downward at apex ; pregonite elongated.

Boby length: $9 \mathrm{~mm}$.

Female : Unknown.

Holotype ð, Yuwandake, Is. Amami-Ôshima, Ryukyus, 4. xi. 1966, Y. Miyatake leg.

Host : Unknown.
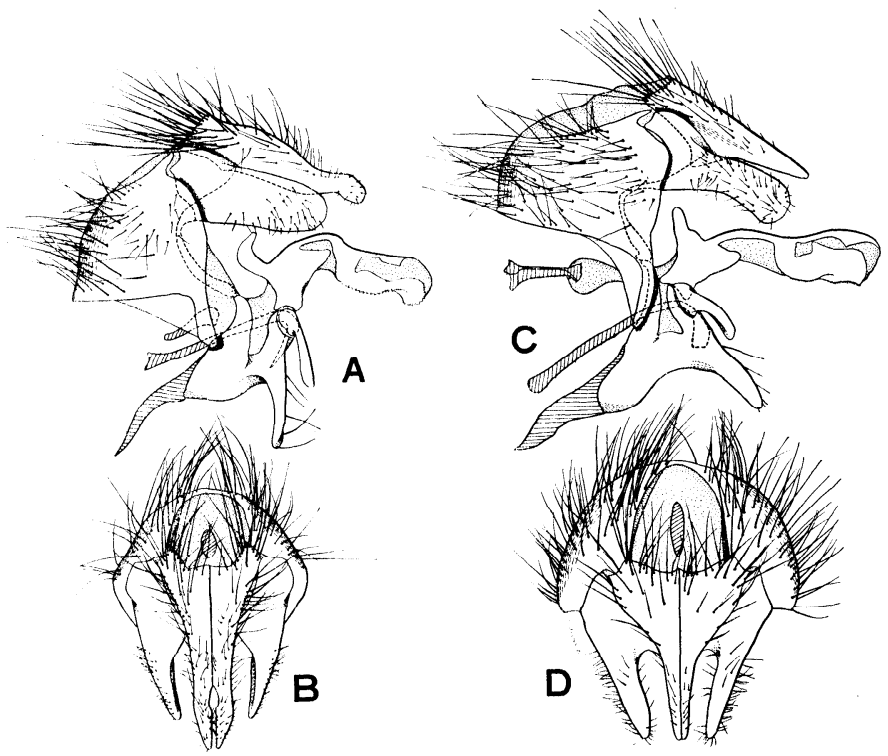

Fig. 5. Male hypopygium.

A, C lateral view; B, D dorsal view. A, B : Eucarcelia orientalis sp. nov. ; C, D : Eucarcelia kockiana Townsend.

Remarks : This species is closely allied to Eucarcelia rufa Baranov, but is different in the broader vertex and not shining black apex of 5 th abdominal tergum.

\section{Eucarcelia villeneuvei Mesnil,1963}

Exoristaleucopheae : Rondani, 1859, Dipt. Ital. Prodr. III : 136. 
Paraexorista flavicans: Brauer \& Bergenstamm, 1891, Denkschr. Akad. Wien LVIII : 322.

Carcelia flavicans : Bezzi \& Stein, 1911, Katal. Paläarkt. Dipt. III: 236.

Carcelia leucopheae: Villeneuve, 1912, Feuille Jeune Natur. : 90.

Carcelia flavicans: Stein, 1924, Die verbr. Tach. Mitteleuropas : 63.

Carcelia flavicans: Baranov, 1931, Inst. f. Hyg. Arb. Parasitol. Abt. 3: 30.

Carcelia (Eucarcelia) confudens: Mesnil, 1944, Larvaevorinae (Tachininae) in Lindner, "Die Flieg. der paläarkt. Reg. 64 g" : 31.

Eucarcelia leucopheae: Herting, 1960, Monog. zur Angew. Ent. 16 : 89.

Eucarcelia villeneuvei Mesnil, 1963, Bull. Inst. r. Sci. nat. de Belgique XXXIX (24) : 3 .

Eucarcelia villeneuvei : Mesnil \& Pschorn-Walcher, 1967, Mushi 41 (12). : 153.

This species is very closely allied to E. pollinosa Mesnil, but is differentiated by the greyish pollinosity and only 1 posterior seta of fore tibia.

I could obtain only one male of this species on the Is. Tsushima, Kyushu.

Distribution: Europe and Japan (Hokkaido and Kyushu).

Specimen examined : $1 \delta^{\Uparrow}$, Hitakatsu, Is. Tsushima, Kyushu, 27. v. 1968, H. Shima leg.

Host : Unknown.

\section{Eucarcelia kockiana (Townsend, 1927)}

(Fig. 5C, D)

Carcelia kockiana Townsend, 1927, Suppl. Ent. XVI : 65.

Eucarcelia kockiana : Baranov, 1934, Trans. R. ent. Soc. London LXXX11 : 396.

Carcelia kockiana: Takano, 1956, Ann. Rep. Co-oper. Res. Minist. Educ., 1955, Agr. : 60 .

Carcelia evolans: Koizumi, 1964, in Yasumatsu \& Watanabe "Tentat. Cat. Ins. Nat. Enem. Injur. Ins. Japan, Pt. I" : 122.

Eucarcelia kockiana : Mesnil \& Pschorn-Walcher, 1967, Mushi 41 (12):152.

Male : Head black; gena below eye and anterior part of parafacial reddish ; epistoma pale yellow ; parafrontal, parafacial, face and occiput silvery white pollinose ; pollinosity on paraf rontal becoming slightly yellowish to vertex; frontal stripe brown-black ; antenna black, base of 3rd segment narrowly reddish ; arista brown-black ; palpus yellow. Facial length slightly shorter than frontal one in profile; vertex nearly $1 / 2 \mathrm{x}$ as wide as single eye ; frontal stripe widened anteriorly, nearly as wide as parafrontal at middle; parafacial narrowed below, $3 / 4 \mathrm{x}$ as wide as the width of $3 \mathrm{rd}$ antenna1 segment; face well concave, nearly $2 \mathrm{x}$ as long as wide ; epistoma slightly 
projected forward, but not beyond vibrissal angle ; gena nearly 1/10 of eye height. Parafrontal with short and fine hairs ; inner vertical bristle nearly $1 / 4$ of eye height ; outer vertical bristle hair-like and indistinct ; 2 fine postocellar setae ; 1 fine and long postvertical seta on each side (rarely absent) ; 2 strong ocellar bristles ; 2 subequally long reclinate inner orbital bristles, nearly as long as ocellar bristle ; 7-8 frontal bristles, of which 2-3 are descending to parafacial; vibrissa slightly longer than the entire antennal length ; facial ridge with several fine setae on its lower 1/6. Antenna with 3rd segment nearly $3.5 \mathrm{x}$ as long as 2 nd. Arista with 2 nd segment very short, shorter than wide; 3rd segment thickened on basal 1/3. Palpus club-like in form, flattened at middle and widened apically, with black hairs.

Thorax shining black, postalar callus and anterior part of hypopleura reddish, with yellowish grey-white pollinosity; pollinosity on pleura more or less whitish; 5 narrow black vittae present on dorsum, of which middle one is indistinct on prescutum. Scutellum yellowish, basally broadly darkened, with thin yellowish white pollinosity. Hairs fine, short and dense on dorsum, on pleura longer and on scutellum more erect and strong; 4 humerals ; $3+3$ acrostichals ; $3+4$ dorsocentrals ; 2 notopleurals ; $1+1$ sternopleurals, anterior one weaker ; 6-9 hypopleurals, uppermost one hairlike; lateral and apical scutellar bristles subequal in length, and nearly $7 / 10 \mathrm{x}$ as long as subapical scutellar bristle ; basal scutellar bristle slightly shorter than subapical scutellar bristle ; preapical scutellar bristle nearly $1 / 2 \mathrm{x}$ as long as subapical scutellar bristle. Distance between two subapical scutellar bristles nearly $5 / 3 \mathrm{x}$ as long as that between basal and subapical scutellar bristles of same side.

Wing hyaline, with slightly yellowish tinge anteriorly ; veins brown ; basicosta brown to reddish brown; calypter white. Basal portion of vein $R_{4+5}$ with 1-4 fine setae ; costal spine indistinct. Second and 4th costal section subequal in length and nearly $5 / 9 \mathrm{x}$ as long as 3rd. Length of vein $\mathrm{M}_{1}$ from $t p$ to bending portion nearly $1 / 2 \mathrm{x}$ as long as that from bending portion to anterior end of vein $\mathrm{M}$,. Cell $\mathrm{R}_{5}$ widely opened before wing tip.

Legs entirely black or tibia somewhat brownish; pulvillus yellow. Hind coxa without seta on posterodorsal margin ; fore tibia with 1 posterior seta; mid-tibia with 1 anterodorsal and 2 posterodorsal setae, without ventral seta; hind tibia with a row of closely set anterodorsal setae, of which middle one is stronger, 1 posterodorsal and several ventral setae. Fore claw and pulvillus longer than 5th tarsomere.

Abdomen shining black, sides of 2nd and 3rd terga slightly reddish; anterior $3 / 5$ of each tergum with yellowish grey pollinosity ; venter thin whitish pollinose. Hairs fine and dense, on 5th tergum more sparse and erect; 2nd tergum with 2 short and fine marginal bristles; 3rd tergum with 2 short marginal bristles ; 4 th tergum with a row of marginal 
bristles : 5th tergum with rows of marginal and discal bristles mixed with erect bristle-like hairs.

Male genitalia : Cercus in profile gradually becoming slender to apex but more slender than that of E.excisa; surstylus nearly as long as cercus, slightly widened to apex; basiphallus of aedeagus with right-angled projected epiphallus.

Female : Closely resembling male but differing as follows : Vertex nearly $2 / 3 \mathrm{x}$ as wide as single eye; outer vertical bristle distinct, nearly $2 / 3 \mathbf{x}$ as long as inner vertical bristle; anterior inner orbital bristle stronger than posterior one and nearly as strong as ocellar bristle; $\mathbf{2}$ strong outer orbital bristles nearly as long as anterior inner orbital bristle; 4-7 frontal bristles, of which 1-3 descend to parafacial; abdomen not flattened and without reddish side.

Body length: 8-12 mm.

Distribution: Japan (Honshu, Kyushu and Ryukyus), China, Formosa and Java.

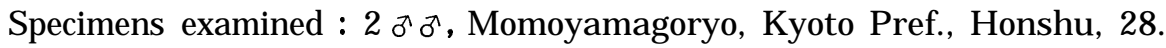
viii. 1967, H. Shima leg. ; 1 ð, Minami Park, Fukuoka Pref., Kyushu, 16. v. 1966, H. Shima leg. ; 1 우, Matsuura City, Nagasaki Pref., Kyushu, 3. xi. 1965, Y. Ikezaki leg.; 1 o , Mt. Iwaya, Nagasaki Pref., Kyushu, 29. ix. 1963, E. Ninomiya leg. ; 1 우, Nagasaki City, 28. xi. 1963, reared from larva of Lepidoptera, E. Ninomiya leg. ; 1 우, Iriki-Pass, Kagoshima Pref., Kyushu, 16. x. 1966, K. Kanmiya leg. ; 1 우, Kurinodake Spa, Mts. Kirishima, Kagoshima Pref., 9. ix. 1958, reared from Melanitis phedima oitensis Matsumura, H. Tanaka leg. ; 1 o , Kurio, Is. Yakushima, Kagoshima Pref., 27. vii.1967, A.

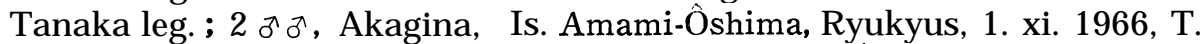
Okuno \& Y. Miyatake leg.; 1 § , Naze, Is. Amami-Ôshima, 13. vii. 1933, T. Esaki \& K. Yasumatsu leg.

Hosts : Aedia leucomelas Linné; *Melanitis phedima oitensis Matsumura.

Remarks: This species is very closely related to the European species, $E$. evolans (Wiedemann), but is differentiated by the narrower parafacial and gena.

Eucarcelia excisa (Fallen, 1820)

(Fig. 6C, D)

Tachina excisa Fallen, 1820, Dipt. Suec. Mus. : 32 .

Tachina excisa: Meigen, 1824, Syst. Beschr. IV : 395.

Exorista excisa: Meigen, 1824, Ibid. VII: 256. 
Carcelia bombycivora Robineau-Desvoidy, 1830, Mém. Acad. Sci. Inst. France II: 181.

Carcelia scutellaris Robineau-Desvoidy ?, 1830, Ibid. : 181.

Carcelia aurifrons Robineau-Desvoidy ?, 1830, Ibid. : 182.

Dobinia genitalis Robineau-Desvoidy ?, 1847, Ann. Soc. Ent. France VII: 273.

Exorista flavicans Macquart ?, 1849, Ann. Soc. Ent. France VII : 391.

Exorista flavicans?: Rondani, 1859, Dipt. Ital. Prodr. III : 133.

Exorista separata Rondani, 1859, Ibid. : 134.

Exorista excisa: Schiner, 1862, Fauna Austr. I : 462.

_ Exorista excavata: Schiner, 1862, Ibid. I: 462.

Carcelia sericea Robineau-Desvoidy, 1863, Dipt. Env. Paris I : 224.

Carcelia canora Robineau-Desvoidy, 1863, Ibid. : 325.

Sisyropa excisa : Brauer \& Bergenstamm, 1891, Denkschr. Akad. Wien LVIII : 345.

Carcelia separata: Stein, 1924, Die verbreit. Tach. Mitteleuropas: 65.

Carcelia excisa: Baranov, 1931, Inst. f. Hyg. Arb. Parasit. Abt. 3: 29.

Carcelia separata: Baranov, 1931, Ibid. : 30.

Carcelia sericea : Villeneuve, 1931, Konowia X : 73.

Carcelia separata : Sellers, 1943, Proc. U. S. nat. Mus. 93 (3157) : 56.

Carcelia (Eucarcelia) excisa : Mesnil, 1944, Larvaevorinae (Tachininae) in Lindner "Die Flieg. der paläarkt. Reg. 64g": 34.

Eucarcelia excisa: Herting, 1960, Mon. zur Angew. Ent. 16: 87.

Eucarcelia bombycivora : Mesnil, 1963, Bull. Inst. r. Sci. nat. de Belgique XXXIX (24) : 3.

Carcelia excia (!): Koizumi, 1964, in Yasumatsu \& Watanabe “Tentat. Cat. Ins. Nat. Enem. Injur. Ins. Japan Pt. I" : 122.

Carcelia excia (!) separata : Koizumi, 1964, Ibid. : 123.

Eucarcelia bombycivora : Mesnil \& Pschorn-Walcher, 1967, Mushi 41 (12) : 152.

Eucarcelia excisa : Mesnil \& Pschorn-Walcher, 1967, Ibid. : 152.

This is a rather commonly occurring species in Japan. This species represents two forms in the coloration of pollinosity, the greyish and golden yellowish forms. Mesnil(1963) examined the Fallen's type specimens and assigned the name $\boldsymbol{E}$. bombycivora for greyish form, but I think that the structure of male genitalia is entirely the same in both forms.

Male genitalia: Closely allied to E. kockiana, but surstylus wider than in kockiana; sutstylus distinctly shorter than cercus. 
Distribution: Japan (Hokkaido, Honshu, Shikoku, Kyushu and Ryul yus ), Europe, India, Ceylon, Thailand and Java.
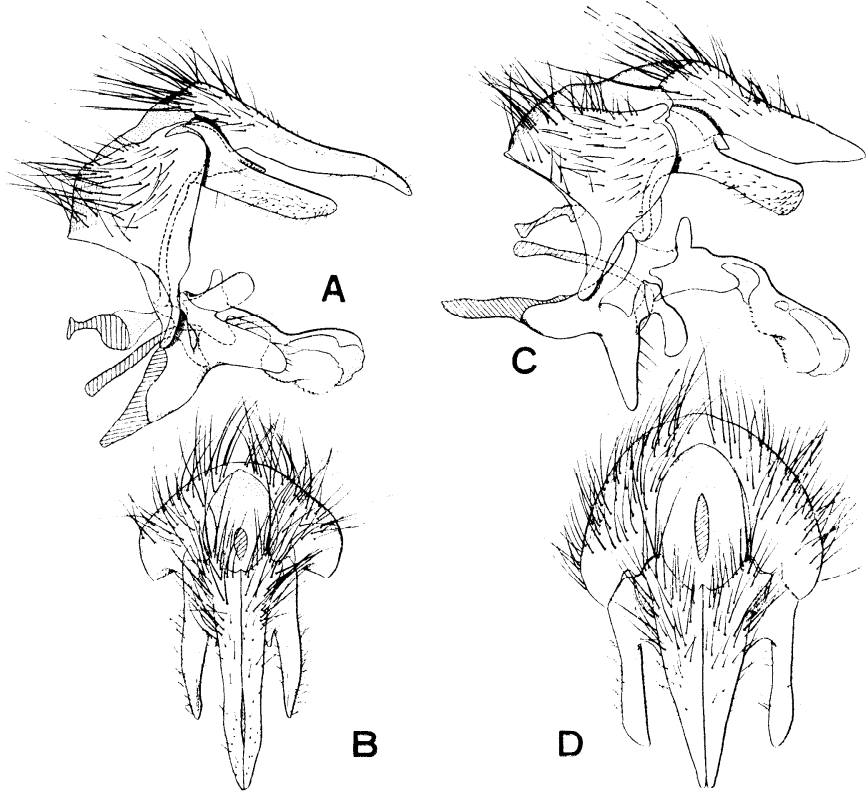

Fig. 6. Male hypopygium.

A, C lateral view; B, D dorsal view. A, B : Eucarcelia

pollinosa Mesnil ; C, D : Eucarcelia excisa Fallen.

Specimens examined : 1 ๙ Mt. Rausu (200-900m), Hokkaido, 4. viii. 1967, H. Shima leg., 24 ðð, Berabonai, Ashoro, Hokkaido, 22 \& 24. vii .1967, H. Shima \& T. Saigusa leg. ; 4 ðð 1 우, Kiyokawa, Ashoro, 23. vii. 1967, T. Saigusa, H. Shima \& A. Nakanishi leg. ; 2 ð, Pirikapetanu, Mts. Satsunai, Hokkaido, 27. vii. 1967, H. Shima leg. ,1 §, Fujikawa, Nukabira, Hokkaido, 19. vii. 1967, H. Shima leg. ; 1 ð, Otofukegawa, Nukabira, 20. vii. 1967, H. Shima leg. ; 1 우, Kutsukake, Karuizawa, Nagano Pref., Honshu, 11. vii. 1966, H. Shima leg.; 3 ðð 3 우우, Nagahinata, Karuizawa, 12. vii. 1966, H. Shima, Y. Miyatake \& M. Honda leg.; 1 ð, Cape Muroto, Kochi Pref., Shikoku, 7. vi. 1959, T. Ishihara leg., 1 ऽ, Inunaki Pass, Fukuoka Pref., Kyushu, 7. vi. 1931, T. Esak, H. Hori \& K. Yasumatsu leg. ; 1 우, Hakozaki, Fukuoka City, 12. vi. 1967, H. Shima leg. ; 1 ð, Hakozaki, Fukuoka City, 5. vii. 1967, reared from Calospilus miranda Butler, H. Shima leg. ; $3 \delta^{\nwarrow}$, Minami Park, Fukuoka City, 13. x. 1966, H. Shima leg. ; $15 \overbrace{}^{\nwarrow}$, Mt. Konpira, Nagasaki Pref., 13. x. 1963, E. Ninomiya leg. ; 1 우, Momiki-Kaimochi, Gokanoshô, Kumamoto Pref., 21. vii. 1966, R. Oishi leg. ; 1우, Osuzuyama, Miyazaki Pref., 20. v. 1966, K. Kanmiya leg. ; 1 우, Jonodan, Mt. Shibi, Kagoshima Pref., 13. viii. 1965, H. 
Tanaka leg.; 1, Takachihokawara, Mts. Kirishima, Kagoshima Pref ., 26. vii. 1965, H. Shima leg. , $6 \precsim \precsim$, Mt. Kurino, Mts. Kirishima, Kagoshima Pref., 16. vii. 1967, A. Tanaka leg. ; $1 \precsim$, Kurinodake Spa, Mts. Kirishima, 27. vii. 1963, H. Tanaka leg. , 4 ðð, Terayama Park, Kagoshima City, 29. v. 1965, H. Shima leg. ; 1 ๙ , Uearatacho, Kagoshima City, 27. iv. 1965, A. Tanaka leg. ;1우, Kurio, Is. Yaku, Kagoshima Pref., 26. vii. 1967, A. Tanaka leg. ; 12 ॐ , Yuwandake, Amami-Ôshima Is., Ryukyus, 4. xi. 1966, Y. Miyatake \& T. Okuno leg., 2 우우, Ohara, Tokunoshima Is., Ryukyus, 8. xi. 1966, T. Okuno leg. ; $2 \precsim ð$, Asahigaoka, Tokunoshima Is., 7. xi. 1966, T. Okuno leg.

Hosts :Calospilus miranda Butler ; Dendrolimus spectabilis Butler ; Phalera flavescens Bremer et Grey ; Lymantria dispar Linné.

\section{Eucarcelia pollinosa (Mesnil, 1941) \\ (Fig. 6A, B)}

Paraexorista rutilla : Brauer \& Bergenstamm (nec Rondani), 1891, Denkschr. Akad. Wien LVIII : 320.

Carcelia rutilla : Villeneuve, 1912, Feuille Jeunes Nat. : 90.

Carcelia rutilla: Stein, 1924, Die verbreit. Tach. Mitteleuropas : 67.

Carcelia rutilla : Baranov, 1931, Inst. f. Hyg. Arb. Parasit. Abt. 3 : 38.

Carcelia obesa : Ringdahl, 1937, Ent. Tidskr. 58 : 38.

Carcelia pollinosa Mesnil, 1941, Bull. Soc. ent. France 46 : 98.

Carcelia (Eucarcelia) obesa : Mesnil, 1944, Larvaevorinae (Tachininae) in Lindner "Die Flieg. der paläarkt. Reg. 64g" : 35.

Eucarcelia rutilla : Herting, 1960, Monog. zur Angew. Ent. 16 : 88.

Eucarcelia pollinosa : Mesnil, 1963, Bull. Inst. r. Sci. nat. de Belgique XXXIX (24) : 3 .

This species is closely allied to E. excisa, but is easily distinguishable by the very strong bristles on scutellum and abdomen, 2 posterior setae of fore tibia and structure of male genitalia.

Male genitalia : Cercus very elongated ; surstylus short, slightly over $1 / 2$ of length of cercus; ventral part of distiphallus of aedeagus rather wide.

Distribution: Japan (Hokkaido, Honshu and Kyushu) and Europe.

Specimens examined : 1 우 Akanmachi, Kushiro, Hokkaido, 31. vii. 1967, H. Shima leg., 1 ㅇ, Shiraike, Niigata Pref., Honshu, 18. vii. 1966, Y. Miyatake leg. ; 1 ๙, Nagahinata, Karuizawa, Honshu, 12. vii. 1966, H. Shima leg. ; 1 , Mt. Wanizuka, Miyazaki Pref., Kyushu, 25. v. 1966, A. Tanaka leg.

Host : Unknown. 


\section{Eucarcelia japonica sp. nov.}

(Fig. 7B)

Male: Head black; anterior part of parafacial and gena below eye reddish, epistoma pale yellow ; parafrontal, parafacial, occiput and face silvery pollinose ; frontal stripe brown black; antenna black; arista brown-black; palpus yellow. Facial length slightly longer than frontal one in profile; vertex nearly $3 / 5-1 / 2 \mathrm{x}$ as wide as single eye width; frontal stripe widened anteriorly, slightly over $1 / 2$ of the width of parafrontal at middle ; parafacial narrowed below, narrower than the width of 3rd antenna1 segment at middle; gena nearly $1 / 9$ of eye height. Parafrontal with rather dense and weak hairs ; inner vertical bristle strong; outer vertical bristle indistinct; ocellar bristle strong, nearly as long as anterior inner orbital bristle ; 2 reclinate inner orbital bristles, anterior one stronger ; 7 frontal bristles, of which 3 are descending parafacial and the undermost one is nearly at the level of base of arista ; 2 postocellar setae; 1 postvertical seta on each side; facial ridge with 3-4 fine setae on its lower 1/8. Antenna long and wide ; 3rd segment nearly $4 \mathrm{x}$ as long as $2 \mathrm{nd}$. Arista with 2 nd segment wider than long; 3rd segment thickened on nearly basal 1/3. Palpus slightly widened and flattened apically, with dense hairs.
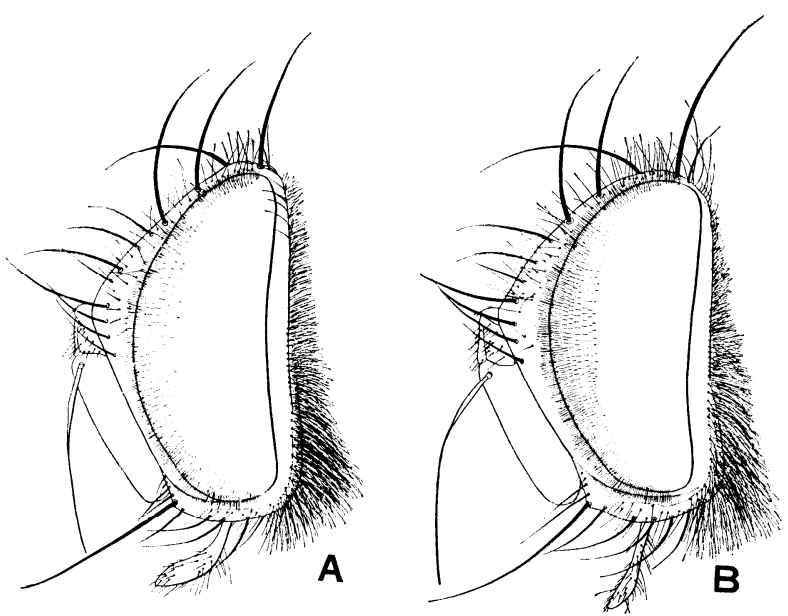

Fig. 7. Head in profile.

A: Eucarcelia orientalis sp. nov., B : Eucarcelia japonica sp. nov.

Thorax shining black, postalar callus slightly reddish; dorsum with dull greyish pollinosity ; 5 black vittae present on prescutum and scutum; pollinosity on pleura whitish ; scutellum entirely black with dull greyish pollinosity. Hairs on dorsum dense and fine, on pleura longer; 3 humerals, 
foremost one weak ; 1 weak prehumeral ; 2 posthumerals ; $3+3$ acrostichals ; - 3-f-3 dorsocentrals; $1+3$ intraalars; 3 supraalars; 1 presutural; 1 weak intrapostalar ; 2 notopleurals ; $1+1$ sternopleurals ; 5 -7 hypopleurals. Scutellum with erect and rather sparse hairs; subapical scutellar bristle nearly $2 \times$ as long as scutellum ; apical scutellar bristle nearly $3 / 4 \mathrm{x}$ as long as subapical scutellar bristle, and slightly longer than lateral scutellar bristle ; preapical scutellar bristle short and fine. Distance between two subapical scutellar bristles nearly $1.5 \mathrm{x}$ as long as that between basal and subapical scutellar ones of same side.

Wing hyaline, with slightly yellowish tinge anteriorly ; basicosta black ; veins brown; calypter pale yellowish white. Costa1 spine indistinct: basal portion of vein $R_{4+5}$ with 3 fine setae. Second costal section nearly $3 / 7 \times$ as long as 3rd, and slightly shorter than 4 th; bending portion of vein $M_{1}$ nearly right-angled. Cell $R_{5}$ opened before wing tip.

Legs entirely black; pulvillus yellow. Hind coxa bare on posterodorsal margin. Fore tibia with 1 posterior seta; mid-tibia with 1 anterodorsal and 2 posterodorsal setae, ventral seta absent; hind tibia with a regular row of anterodorsal setae, of which middle one is stronger, 1 posterodorsal and 2-3 ventral setae. Fore claw and pulvillus longer than 5th tarsomere.

Abdomen rather long ovate; entirely shining black ; anterior $1 / 2$ of 3rd and 4 th terga and $1 / 5$ of 5 th tergum with rather thin whitish pollinosity ; black median longitudinal line distinct. Hairs on dorsum rather strong and short, on mid-dorsal region and on 5th tergum sparser; hairs becoming sparse posteriorly ; 2nd and 3rd terga with 2 marginal bristles; 4th tergum with a row of marginal bristles; 5th tergum with an irregular row of discal and a regular row of marginal bristles mixed with erect bristlelike hairs.

Body length : $8 \mathrm{~mm}$.

Female : Unknown.

Holotype ð`, Kii-Oshima, Wakayama Pref., Honshu, 21-24. v. 1964, T. Kumata leg.

Paratype: $1 \delta^{\curvearrowright}$, same data as holotype.

Host: Unknown.

Remarks : This species is closely related to E.sussurans (Rondani) and E. melancholica Mesnil, but easily differentiated as follows :(1) scutellum entirely black, (2) fore tibia with only 1 posterior seta, (3) vertex wider, (4) wing not darkened at wing margin, (5) ocellar bristle stronger.

Eucarcelia nudicauda Mesnil, 1967

Eucarcelia nudicauda Mesnil, 1967, Mushi 41 (2) : 37. 
Eucarcelia nudicauda: Mesnil \& Pschorn-Walcher, 1967, Mushi 41 (12) : 152.

This species is characteristic in its golden yellowish pollinosity, short and recumbent hairs on 5th abdominal tergum, entirely blackish tibia, 2 posterior setae of fore tibia and fine ocellar bristle. I could not obtain this species.

Distribution : Japan (Honshu).

Host : Unknown.

\section{References}

Baranov, N. (1931) Beitrag zur Kenntnis der Raupenfliegengattung Carcelia R.-D. Inst. f. Hyg. Arb. Parasit. Abt. $3: 1-45$.

- (1934) Übersicht der orientalischen Gattungen und Arten des Carcelia-Komplexes (Diptera : Tachinidae). Trans. R. ent. Soc. London LXXX11 :387-408.

Bezzi, M. (1925) Diptera Brachycera and Athericera of the Fiji Island. London, British Museum: $220 \mathrm{pp}$.

Emden, F. I. van (1954) Handbooks for the identification of British insects, Diptera Cyclorrhapha, Calyptrata (1), Section (a). R. Ent. Soc. London: 133 pp.

-- \& W. Hennig (1956) in Tuxen "Taxonomist's glossary of genitalia in insects" :111122.

I-Ierting, B. (1960) Biologie der westpaläarktischen Raupenfliegen, Dipt., Tachinidae. Monog. zur Angew. Ent. 16: 188 pp.

(1961) Revision einiger europäischer Raupenfliegen (Dipt., Tachinidae). Ann. Naturk. Mus. Wien 63: 423-429.

Koizumi, K. (1964) in Yasumatsu and Watanabe "A tentative catalogue of insect natural enemies of injurious insects in Japan, Part I": 121-129.

Lundbeck, W. (1927) Diptera Danica VII: 560 pp.

Mesnil, L. P. (1941) Notes synonymiques. Bull. Soc. ent. France 46: 98.

- (1944) Larvaevorinae (Tachininae) in Lindner "Die Fliegen der paläarktischen Region 64g" : 1-58.

- (1950) Notes sur les Carceliina (Dipt., Tachinidae) et révision des espèces d'Afrique. Rev. 2001. Bot. Afr. XL111 (1-2); 1-24.

- (1953) Nouveaux Tachinaires d'Orient(1 $1^{\text {re }}$ partie). Bull. et Ann. Soc. Entom. de Belgique 89 (III-IV) : 86-114.

- (1957) Nouveaux Tachinaires d'Orient(Deuxième serie). Mém. Soc. Roy. Ent. Belg. XXVIII : $1-80$.

- (1963) Nouveaux Tachinaires de la region paléarctique principalement de l'URSS et du Japon. Bull. Inst. r. Soc. nat. Belg. XXXIX (24) : 1-56.

— (1967) Tachinaires paléarctiques inédits (Diptera). Mushi 41 (2) : 37-57.

— \& H. Pschorn-Walcher (1967) A preliminary list of Tachinidae (Diptera) from Japan. Mushi 41 (12) : 149-174.

Sabrosky, W. \& P. H. Arnaud (1965) in Stone et al. "A catalogue of the Diptera of America North of Mexico." Washington: 961-1108.

Sellers, W. F. (1943) The nearctic species of parasitic flies belonging to Zenillia and allied genera. Proc. U. S. nat. Mus. 43(3157): 108 pp. 
Stein, P. (1924) Die verbreitesten Tachiniden Mitteleuropas nach ihren Gattungen und Arten. Arch. Naturg. Abt. A 90 (6): 1-271.

Takano, S. (1951) Systematic and ecological studies of Tachinoidea (in Japanese). Ann. Rep. Co-oper. Res. Minist. Educ., 1955, Agr. : 60-63.

Townsend, C. H. T. (1927) Fauna sumatrensis, Diptera Muscoidea III. Suppl. Ent. XVI : 56-76.

(1936) Manual of Myiology IV, São Paulo : 309 pp.

(1941) Ibid. XI: 342 pp.

Uéda, S. (1960) A new species of the genus Carcelia from Japan (Diptera:Larvaevoridae). Ins. Matsum. 23 (2) : 112-114.

Villeneuve, J. (1926) Descriptions de nouveaux Tachinidae de l'Europe méridionale. Bull. Ann. Soc. Ent. Belg. V : 197-200.

(1931) Aperçus critiques sur les mémoire de P. Stein: "Die verbreitesten Tachiniden Mitteleuropas." Konowia X : 47-74.

(1932) $\mathrm{N}$ ot ices dipterogiques. Konowia XI : 29-30. 